$\underline{\text { Review Articles }}$

\title{
Epidemiology of Activated Protein C Resistance and Factor V Leiden Mutation in the Mediterranean Region
}

\author{
Mehrez M. Jadaon \\ Department of Medical Laboratory Sciences, Faculty of Allied Health Sciences, Kuwait University, Kuwait \\ Correspondence to: Mehrez M. Jadaon. Department of Medical Laboratory Sciences, Faculty of Allied Health Sciences, \\ Kuwait University, Kuwait. P.O. Box 31470 - Sulaibekaht 90805 - Kuwait. Tel.: (965) 6664 3485, Fax: (965) 24983835. \\ Email: mehrez@hsc.edu.kw, mehrezmls99@yahoo.com
}

Competing interests: The authors have declared that no competing interests exist.

Published: September 8,2011

Received: July 11, 2011

Accepted: August 17, 2011

Mediterr J Hematol Infect Dis 2011, 3: e2011037, DOI 10.4084/MJHID.2011.037

This article is available from: http://www.mjhid.org/article/view/8811

This is an Open Access article distributed under the terms of the Creative Commons Attribution License (http://creativecommons.org/licenses/by/2.0), which permits unrestricted use, distribution, and reproduction in any medium, provided the original work is properly cited.

Abstract: Venous thromboembolic disorders (VTE) are serious disorders with high morbidity and mortality rates. Many genetic and acquired risk factors were identified to cause VTE. The most common genetic risk factor is Factor V Leiden mutation (FVL). FVL was found in high percentage of populations of Caucasian origin but was almost absent in non-Caucasians. It was also reported in populations living in North Africa and the Middle East. This review article briefly explains FVL and how it causes VTE, the distribution of FVL worldwide, and then it elaborates on the epidemiology of FVL in the Mediterranean Region and how this brought speculations that FVL might have originated in the Eastern Mediterranean area.

Introduction: Thrombophilia is the term given to abnormal blood coagulation condition leading to increased tendency towards coagulation (hypercoagulability status). People with hypercoagulability are at risk of developing thrombosis, especially venous thromboembolic disorders (VTE) including deep vein thrombosis (DVT) and pulmonary embolism (PE). VTE is a significant cause of morbidity and mortality in many countries with an annual incidence of $1 / 1000 .^{1-4}$ Many genetic and acquired risk factors for the development of VTE were identified. In fact, the WHO expert group (1996) defined thrombophilia as a tendency to develop VTE that may be genetically determined, acquired or both. ${ }^{5}$ Genetic factors include activated protein $\mathrm{C}$ resistance (APC-R) associated with Factor V Leiden mutation (FVL), Prothrombin G20210A mutation associated with high levels of prothrombin, genetic deficiencies of proteins $\mathrm{C}, \mathrm{S}$ and antithrombin, and others. Acquired risk factors include lupus anticoagulants, pregnancy, use of contraceptives, major surgeries, cancer, inflammations, and others. This review article focuses on the epidemiology of APC$\mathrm{R} / \mathrm{FVL}$ in the Mediterranean area. For a better understanding of the pathophysiology involved in causing hypercoagulability by APC-R/FVL, it may be helpful to start by a quick revision of the process of coagulation and its associated natural anticoagulants.

Blood Coagulation: Normally, blood loss through injured vessels is prevented by a normal physiological process called "Hemostasis". Normal human 


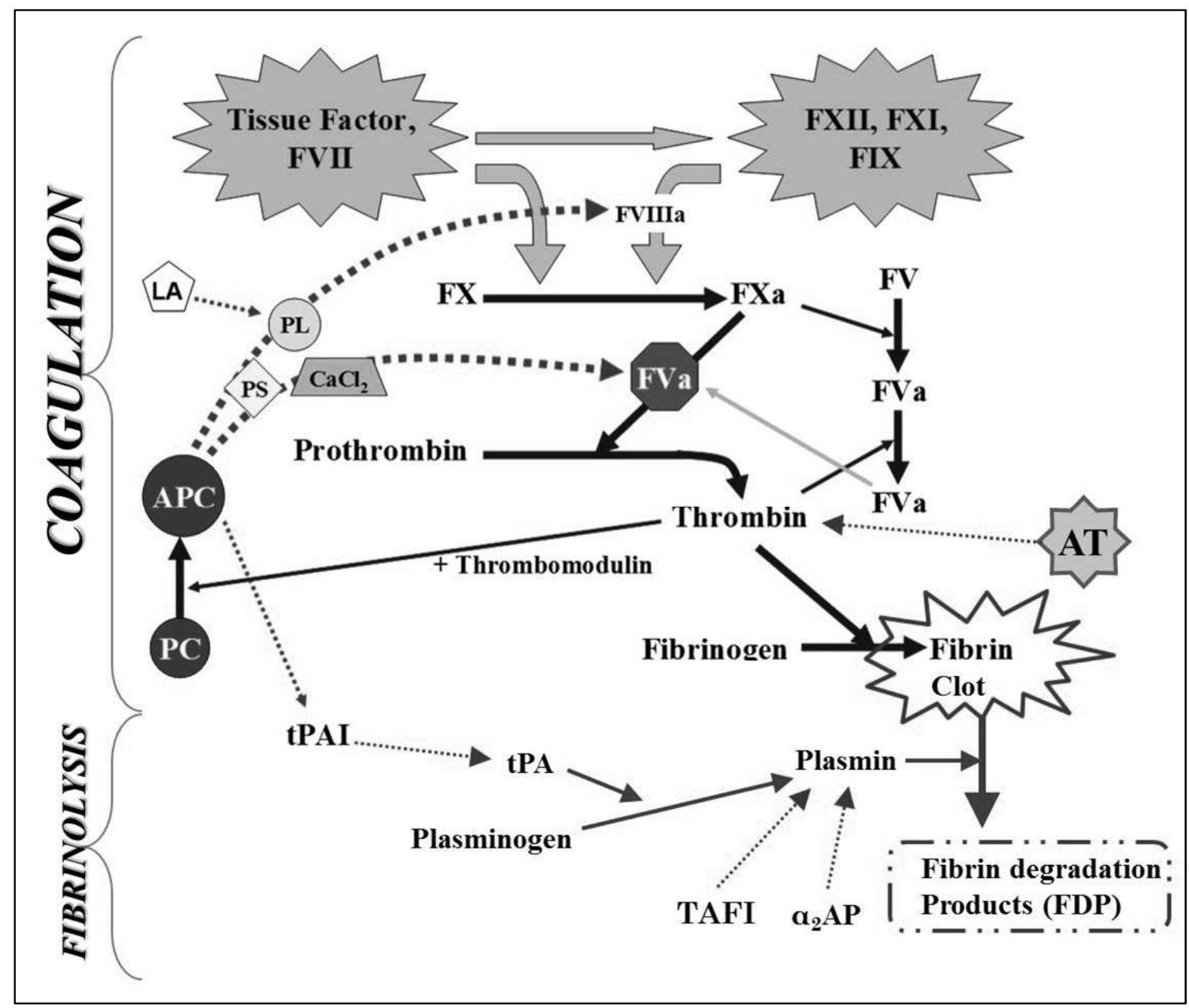

Figure 1. The processes of coagulation and fibrinolysis as a series of chemical reactions leading to the formation of a clot to stop bleeding from the site of injury, and then removing the clot afterwards. Solid lines indicate activation process, while dashed lines indicate inactivation process. Abbreviations: antithrombin (AT), protein C (PC), activated protein C (APC), protein S (PS), phospholipids (PL), lupus anticoagulants (LA), tissue plasminogen activator (tPA), tPA inhibitor (tPAI), $\alpha 2$ antiplasmin ( $\alpha 2 \mathrm{AP})$, thrombin activatable fibrinolysis inhibitor (TAFI).

hemostasis is a balanced system which, on one hand, prevents excessive bleeding from any injured site, while on the other hand maintains blood circulation inside intact blood vessels by inhibiting intravascular coagulation. An efficient hemostatic process possesses intrinsic well-balanced regulatory systems, involving a number of dynamic mechanisms and chemical and physical reactions. It usually includes platelets, blood vessels and the coagulation system. In blood coagulation, a prominent response to an injury is recruited in the form of series of stepwise (cascade) chemical interactions leading to fibrin formation. This complex system involves certain proteins called the plasma clotting factors (enzymes). These enzymes circulate in the blood in an inactive form, and get activated in case of vessel injury. In summary, when a blood vessel is injured, the coagulation cascade is initiated by the release of tissue factor (thromboplastin) and the exposure of intravascular collagen, which activates clotting factors VII and XII, respectively. These clotting factors activate other clotting factors in a stepwise procedure ending up with the formation of a fibrin clot. A fibrin clot, in association with platelets, form a plug that blocks the injured blood vessel, preventing bleeding and allowing for wound healing. After healing, the fibrin clot is dissolved by the enzyme plasmin in a process called fibrinolysis. The whole process is under careful supervision by three main proteins that circulate normally in the blood; namely protein $\mathrm{C}$ (and its active form activated protein $\mathrm{C}$; APC), protein S (PS) and antithrombin (AT). These socalled "natural anticoagulants" monitor the processes of coagulation and fibrinolysis in order to prevent excessive clotting. ${ }^{6,7,8}$ Abnormalities in clotting factors may lead to bleeding problems (hemophilia), while abnormalities in the natural anticoagulants may lead to 


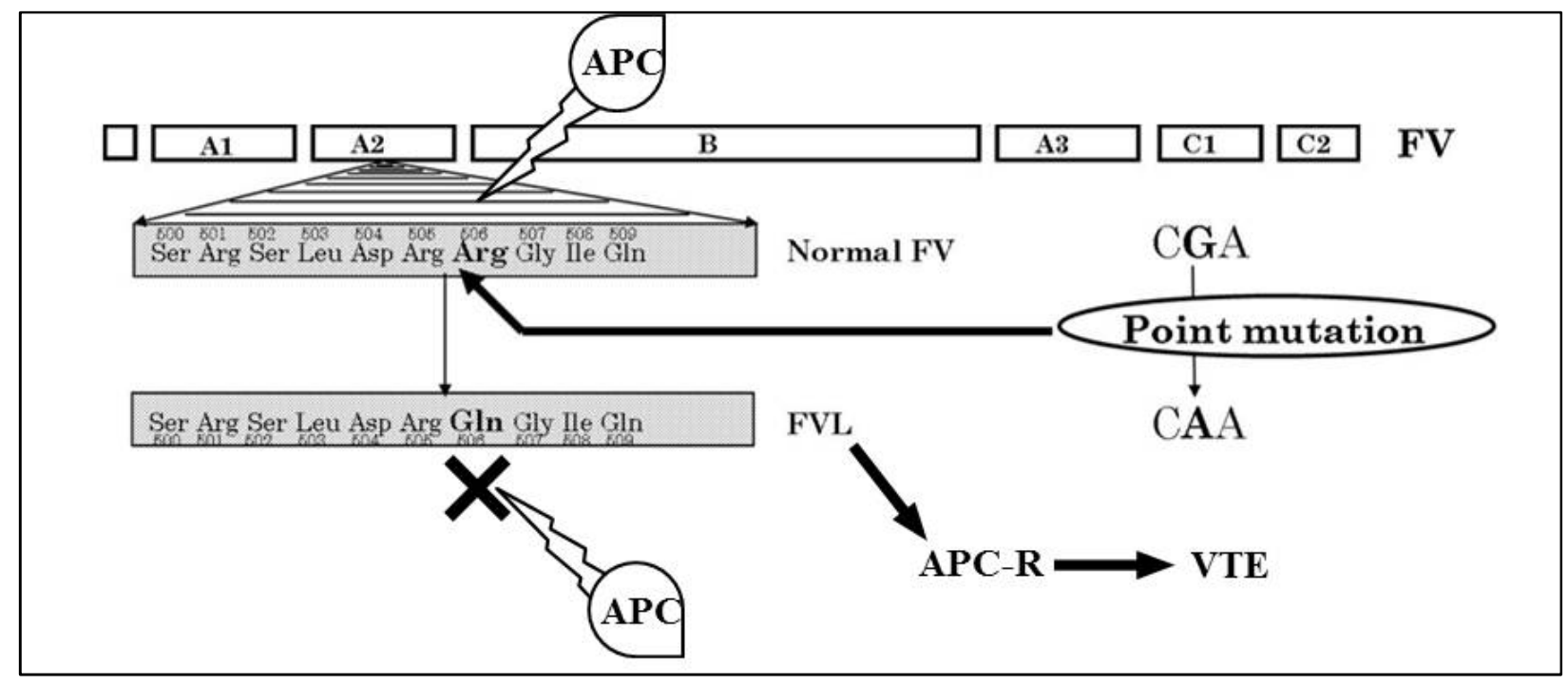

Figure 2. FV molecule showing arginine 506 as a main point of action for APC which is negatively affected by FVL.

hypercoagulability and thrombosis, with certain exceptions in both. Figure 1 gives an illustrative drawing of the process of coagulation and its associated fibrinolysis process and natural anticoagulants.

Activated Protein C Resistance and Factor V Leiden Mutation: In 1993, a Swedish research team led by B. Dahlbäck recognized an unusual phenomenon affecting the coagulation system. They were studying the effect of addition of external APC to plasma of patients with VTE. Normally, APC should inactivate clotting Factor V (FV) (Figure 1) and therefore slow down the coagulation process. However, in certain patients studied by Dahlbäck and his team, this slowing down did not occur. They called this phenomenon "APC resistance", and they originally though this could be due a deficiency in a yet unknown protein that co-helps APC in inactivating FV. ${ }^{9}$ One year later, another group of researchers from Holland, led by R. M. Bertina, discovered a missense point mutation in the FV gene, where adenine (A) replaced guanine $(\mathrm{G})$ at nucleotide position 1691 of exon 10 of the FV gene, only eleven nucleotides upstream of the beginning of intron 10 . They called this mutation as FV Leiden mutation (FVL) after the Dutch city where they made their discovery in. ${ }^{10}$ This nucleotide replacement happened to be in the codon for the amino acid residue arginine 506 (CGA) normally present in the factor $\mathrm{V}$ molecule, creating a new codon (CAA) which is translated as glutamine. In order to inactivate FV, APC needs to recognize arginine at position 506 of the FV molecule (Figure 2). Because of the amino acid change in FVL, APC can no longer inactivate FV efficiently, but FV retains its coagulation capabilities and therefore carriers of FVL develop hypercoagulability which may clinically manifest as VTE episodes. Later studies showed that people with FVL were at higher risk of developing VTE (10-fold in heterozygous carriers and 30 to 140 -fold in homozygous carriers). ${ }^{9-16}$ In addition, most homozygotes for FVL were reported to get at least one VTE event in their life time. ${ }^{17,18}$ This explains the great clinical and scientific consideration this mutation had appealed and the hundreds of studies conducted on its prevalence and risk for developing VTE in almost every part of the world.

World Distribution of Factor $\mathbf{V}$ Leiden: Since its discovery, several studies were conducted to determine the prevalence of FVL mutation in normal subjects and in patients with VTE, as well as to measure the risk value of this mutation in developing VTE. First reports appeared in Europe, which concentrated on populations of Caucasian origin. They found FVL to be present in a quite high percentage of patients with VTE (15-65\%) and healthy subjects (1-15\%). Similar results were obtained when Caucasians where studied in nonEuropean countries like USA, Australia and Israel. Table 1 gives examples of studies on FVL in European and non-European Caucasians. ${ }^{2,3,10,12,14-16,19-64}$ However, when studies where extended to other ethnic groups, FVL was surprisingly found to be very rare in Africans, South-East Asians, Chinese, Japanese, American Indians, Greenland Eskimos and Aboriginals of Australia (Table 2). ${ }^{21,58,61,65-78}$ These findings suggested that FVL might have occurred as a single event sometime in the distant past in a common European Caucasian ancestor, whose offspring are the present time Caucasian carriers of this mutation living in Europe and other countries. This assumption was later strengthened by molecular studies that reported FVL to be always associated with one haplotype of single nucleotides polymorphisms (SNPs), as will be discussed later. Later on, studies were conducted on 
Table 1. Prevalence of FVL in Caucasian patients with VTE and normal subjects living in European and non-European countries. European countries on the Mediterranean Sea are shown.

\begin{tabular}{|c|c|c|c|c|}
\hline & Country & $\begin{array}{c}\text { VTE } \\
\text { patients (\%) }\end{array}$ & $\begin{array}{c}\text { Normal } \\
\text { Population (\%) }\end{array}$ & Reference \\
\hline \multirow{11}{*}{ 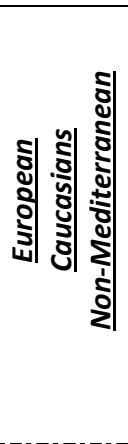 } & UK & ---- & $1.74-5.6$ & 19,20 \\
\hline & Sweden & $41.5-50$ & $7.5-11.4$ & $14,15,19$ \\
\hline & Poland & ---- & 5 & 21 \\
\hline & Netherlands & 21 & 2 & 10,20 \\
\hline & Germany & 30 & 7.1-12 & 22,23 \\
\hline & Belgium & 22 & 3.3 & 24 \\
\hline & Slovakia & $29.5-37.0$ & 4 & 25,26 \\
\hline & Austria & 26 & ---- & 27 \\
\hline & Hungary & 44 & 6.9 & 28,29 \\
\hline & Serbia & 29.9 & 5.8 & 30 \\
\hline & Azerbaijan & --- & 14. & 31 \\
\hline \multirow{10}{*}{ 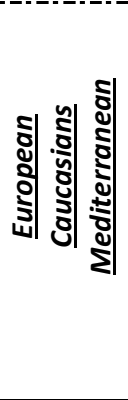 } & Spain & $9.2-26.3$ & $1.6-5.8$ & $32-37$ \\
\hline & France & $9-18$ & $3.5-5.0$ & $38-41$ \\
\hline & French/Spanish & & & \\
\hline & Basques & ---- & $0-0.7$ & 42,43 \\
\hline & Italy & $9.0-42.8$ & $2-13.1$ & $12,44-47$ \\
\hline & Yugoslavia & 15.5 & 4.0 & 48 \\
\hline & Slovenia & 12.9 & 6.3 & 49 \\
\hline & Croatia & $21.0-28.2$ & $2.4-4.0$ & $50-52$ \\
\hline & Albania/Kosovo & ---- & 3.4 & 53 \\
\hline & Greece & $16.2-31.9$ & $2.5-7.0$ & $2,54-57$ \\
\hline \multirow{4}{*}{ 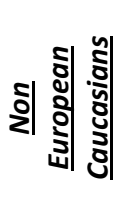 } & USA & 8.6 & $3.2-6.0$ & $3,16,58$ \\
\hline & Australia & ---- & $4-10.2$ & $59-62$ \\
\hline & Israel & ---- & 4.3 & 63 \\
\hline & Brazil & 20 & 2 & 64 \\
\hline
\end{tabular}

Arabs and populations living in the Middle East and North Africa (The MENA region), as summarized in Table 3. ${ }^{31,63,79-133}$ These studies showed a high prevalence of FVL in these populations, who are not usually classified as Caucasians. However, the MENA region is geographically very close to Europe and had witnessed a lot of human movement from and to Europe, and hence such populations are expected to have some Caucasian genes in their DNA. Therefore, the presence of FVL in Arabs and North African populations should not be a surprising upshot.

Factor V Leiden in the Mediterranean Region: Currently, there are 20 countries that have seacoasts on the Mediterranean Sea and therefore are called the Mediterranean countries; 5 are in North Africa, 4 in West Asia and 11 in South Europe. Figure 3 gives a map of the Mediterranean Sea and its countries, showing the prevalence of FVL in these countries which are based on the studies listed in tables 1 and 3. No data could be retrieved from the literature on prevalence of FVL in Libya, Malta, Bosnia or Montenegro. However, one study reported FVL in Yugoslav people which included patients and healthy subjects from all over the former Yugoslavia, and possibly some of their subjects were from Bosnia and
Montenegro. ${ }^{48}$ There were no reports from Albania itself, but one study was conducted in Kosovo, the people of which are considered as Albanians. ${ }^{53}$ In table 1, the prevalence of FVL in the people of the Basques was put separately, although not being a separate country, because of the unique rarity of FVL in these people. ${ }^{42,43}$ This has an important issue which will be discussed later. In Israel, the population consists of a mixture of Palestinian Arabs and other immigrants from different parts of the world, largely being of European Caucasian origin. Therefore, the results there were split between tables 1 and 3 according to the origin of the studied populations.

One may notice that the prevalence of FVL is present in its maximum peak in this part of the World. In addition, there is generally an Eas-to-West decline in prevalence of FVL in these countries. This observation was also noticed by Lucotte et al (2001) who also observed a South-to-North decline of these values in Europe, only when southwestern populations were excluded. ${ }^{134}$ These observations raised discussions in the literature on the exact place where FVL has first appeared.

Has Factor $V$ Leiden originated in the Eastern Mediterranean? As was mentioned before, the first 
Table 2. Prevalence of FVL in non-Caucasian patients with VTE and normal subjects in different parts of the world.

\begin{tabular}{|c|c|c|c|c|}
\hline & $\begin{array}{l}\text { Country/ } \\
\text { Ethnic groups }\end{array}$ & $\begin{array}{c}\text { VTE } \\
\text { patients (\%) }\end{array}$ & $\begin{array}{c}\text { Normal } \\
\text { Population (\%) }\end{array}$ & Reference \\
\hline \multirow[t]{9}{*}{ Asians } & Japan & 0 & 0 & $65-68$ \\
\hline & Korea & 0 & ---- & 69 \\
\hline & China & 0 & 0 & 70,71 \\
\hline & Indonesia & ---- & 0 & 70 \\
\hline & Malaysia & 0.5 & ---- & 72 \\
\hline & Singapore & 5 & ---- & 72 \\
\hline & India & 3 & 1.3 & 21,73 \\
\hline & Pakistan & 1.25 & ---- & 74 \\
\hline & USA & - & 0 & 75 \\
\hline \multirow{5}{*}{$\frac{\text { Africans/ }}{\text { Black }}$} & Ethiopia & $-\cdot-$ & 0 & 70,76 \\
\hline & USA & 1.4 & 0.9 & 58,75 \\
\hline & Sub-Sahara & ---- & 0 & 70 \\
\hline & Ecuador & ---- & 0 & 70 \\
\hline & Venezuela & --- & 4.4 & 77 \\
\hline \multirow[t]{3}{*}{ Amerindians } & Ecuador & -- & 0 & 70 \\
\hline & Venezuela & ---- & 1.25 & 77 \\
\hline & USA & --- & 0 & 75 \\
\hline Eskimos & Greenland & - & 0 & 78 \\
\hline $\begin{array}{l}\text { Indigenous } \\
\text { Australians }\end{array}$ & Australia & ---- & 0 & 61 \\
\hline
\end{tabular}

reports on the prevalence of FVL found high prevalence of FVL in European Caucasians, while the prevalence was almost zero in other ethnic groups. In addition, studies showed an association of FVL with one haplotype in all carriers of the mutation. Therefore, scientists got a perception that FVL has occurred once in the past time in one European Caucasian person. Anthropology proposes that Caucasoid populations who settled in Europe were diverted from Mongoloid populations (who moved to East Asia) around 32 thousands of years ago; therefore FVL should have appeared sometime earlier than 32,000 years ago. ${ }^{2,4,11,135-137}$ It was suggested that the mutation occurred in Europe first, and then spread to other parts of the world. However, the observed highest prevalence of FVL in Eastern Mediterranean countries have raised speculations that FVL might have occurred somewhere there and then spread to Europe. $^{43,99,100,134,138,139}$ The author of this paper has found FVL to be associated with one haplotype in 67 Arabs from Eastern Mediterranean region, which was the same haplotype found in European carriers of the mutation, giving another confirmation that FVL occurred as a single event in the

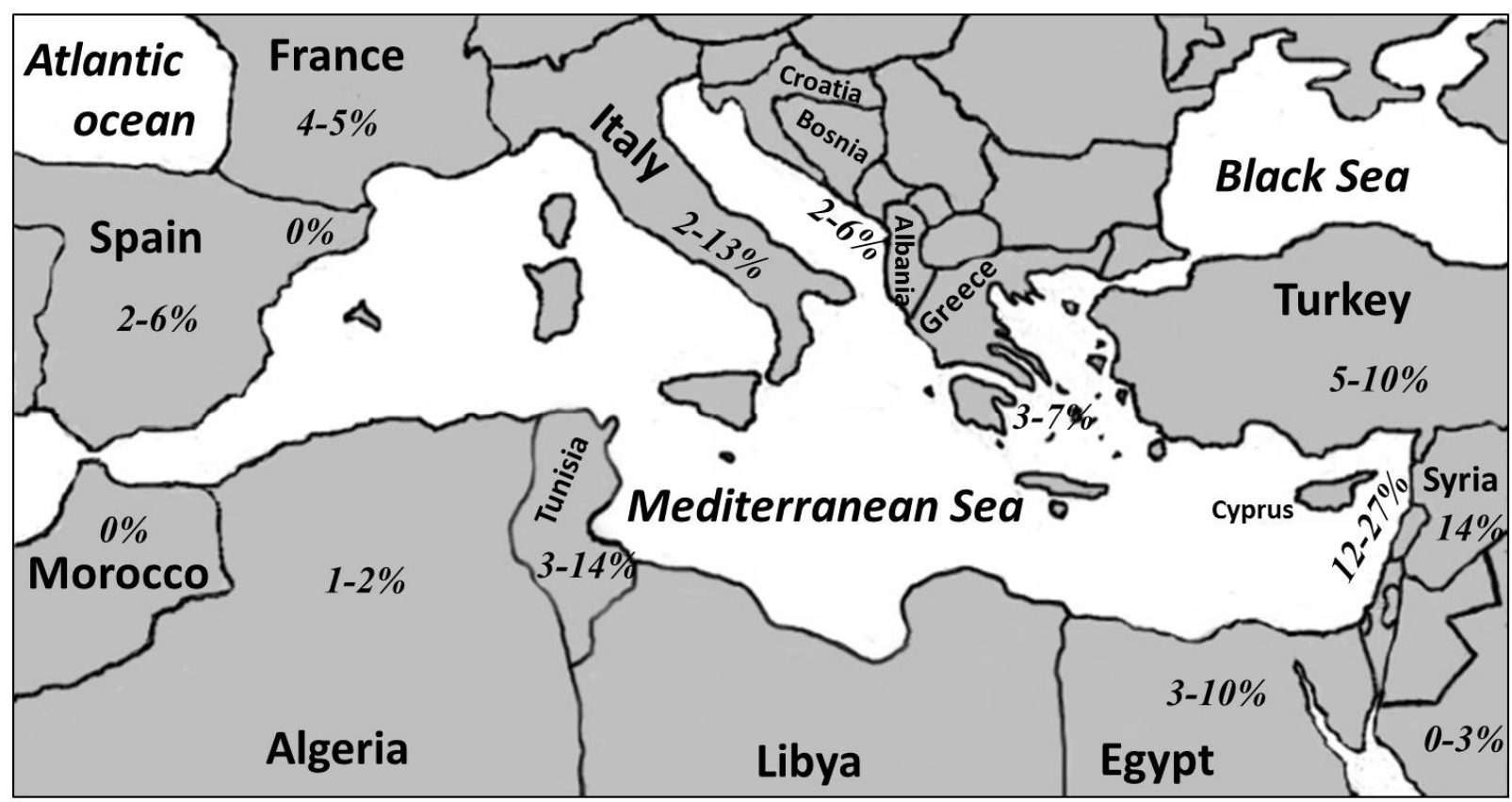

Figure 3. Map of the Mediterranean Sea and its countries showing the prevalence of FVL in healthy populations living there. 
Table 3. Prevalence of FVL in patients with VTE and normal subjects in Arabs and non-Arabs living in different Middle-Eastern and North African countries. Countries on the Mediterranean Sea are shown.

\begin{tabular}{|c|c|c|c|c|}
\hline & $\begin{array}{l}\text { Country/ } \\
\text { Ethnic groups }\end{array}$ & $\begin{array}{c}\text { VTE } \\
\text { patients (\%) }\end{array}$ & $\begin{array}{c}\text { Normal } \\
\text { Population (\%) }\end{array}$ & Reference \\
\hline \multirow{4}{*}{$\begin{array}{c}\text { North Africa } \\
\text { Mediterranean }\end{array}$} & Morocco & ---- & 0 & $79-80$ \\
\hline & Algeria & 13.8 & $1.3-2.0$ & 81,82 \\
\hline & Tunisia & $20.3-24.6$ & $3.0-13.6$ & $83-92$ \\
\hline & Egypt & 30 & $2.5-10.2$ & $93-97$ \\
\hline \multirow{5}{*}{$\begin{array}{c}\text { Middle East } \\
\text { Mediterranean }\end{array}$} & (inside \& outside Israel) & - & $11.7-27.2$ & $63,97,98$ \\
\hline & Lebanon & $9.9-70.6$ & $13.6-18.7$ & $89,92,99-106$ \\
\hline & Syria & ---- & 13.6 & 97,99 \\
\hline & Turkey & $21-30.8$ & $4.6-9.8$ & $31,107,108-115$ \\
\hline & Cyprus & ---- & 13.4 & 116 \\
\hline \multirow{8}{*}{$\begin{array}{c}\text { Middle East } \\
\text { Non-Mediterranean }\end{array}$} & Jordan & $23.9-25.7$ & $10.5-27.2$ & $97,117-122$ \\
\hline & Iraq & ---- & 7.0 & 123 \\
\hline & Kuwait & 15.8 & $2-4.5$ & 97,124 \\
\hline & Saudi Arabia & ---- & $0-2.5$ & $89,123,125$ \\
\hline & Bahrain & 52 & $3.1-14.7$ & 89,126 \\
\hline & Oman & 0 & 0 & 127 \\
\hline & Yemen & ---- & 0 & 63 \\
\hline & Iran & 11.4 & $2.0-10.6$ & $123,128-133$ \\
\hline
\end{tabular}

past even in Arabs. ${ }^{140}$ Castoldi et al (1997) suggested that FVL probably occurred outside Europe. ${ }^{138}$ The rarity of FVL in the French and Spanish Basque populations, which are thought to be the oldest ethnic groups in Europe of Paleolithic origin, has also suggested FVL to occur outside Europe first. ${ }^{42,43}$ Lucotte et al (2001) proposed that FVL expanded in Europe during the Neolithic period, from a probable Anatolian center of origin in Turkey, which has occurred around 10,000 years ago. ${ }^{134}$ This may explain the highest prevalence of FVL in East Mediterranean countries, and that the prevalence decreases when radiating away from this region towards Europe or other parts of the world. Still, more genetic and

\section{References:}

1. Dahlbäck B. Resistance to activated protein C, the Arg506 to Gln mutation in the factor $\mathrm{V}$ gene, and venous thrombosis. Functional tests and DNA-based assays. Pros and Cons. Thromb Haemost 73(5): 739-742, 1995. PMid:7482395

2. Rees DC, Cox M and Clegg JB. World distribution of factor V Leiden. Lancet 346(8983): 1133-1134, 1995. http://dx.doi.org/10.1016/S0140-6736(95)91803-5

3. Ridker PM, Miletich JP, Hennekens CH, Buring JE. Ethnic distribution of Factor V Leiden in 4047 men and women. Implications for venous thrmoboembolism screening. JAMA. 1997;277:1305-1307 http://dx.doi.org/10.1001/jama.277.16.1305

4. Zivelin A, Griffin JH, Xu X, Pabinger I, Samama M, Conard J, Brenner B, Eldor A and Seligsohn U. A single genetic origin for a common Caucasian risk factor for venous thrombosis. Blood 89(2): 397-402, 1997. PMid:9002940

5. Lane DA, Mannucci PM, Bauer KA, Bertina RM, Bochkov NP, Boulyjenkov V, Chandy M, Dahlbäck B, Ginter EK, Miletich JP, Rosendaal FR, Seligsohn U. Inherited thrombophilia: Part 1. Thromb Haemost. 76(5):651-662, 1996. PMid:8950768

6. Davie EW. Biochemical and molecular aspects of the coagulation cascade. Thromb Haemost 74(4): 1-6, 1995. PMid:8578439

7. Kane WH and Davie EW. Blood coagulation factor V and VIII: molecular studies may be needed to detect certain genetic loci or markers that may help in following the movement of carriers of FVL in the Mediterranean region to definitely determine the exact location where FVL might have occurred first.

Conclusions: Molecular and epidemiological studies provide evidences that FVL should have occurred as a single event in the past. The Mediterranean region has the highest prevalence of FVL in the world. This suggests it as the area where this mutation has arisen, possibly 10,000 years ago, and then it was spread to other parts of the world. structural and functional similarities and their relationship to haemorrhegic and thrombotic disorders. Blood 71(3): 539-555, 1988. PMid:3125864

8. Kalafatis M, Rand MD, Mann KG. The mechanism of inactivation of human factor $\mathrm{V}$ and human factor $\mathrm{Va}$ by activated protein C. J Biol Chem. 1994;269:31869-31880. PMid:7989361

9. Dahlbäck B, Carlsson M, Svensson PJ. Familial thrombophilia due to a previously unrecognized mechanism characterized by poor anticoagulant response to ctivated protein C: Prediction of a cofactor to activated protein C. Proc Natl Acad Sci USA. 1993;90:1004-1008. http://dx.doi.org/10.1073/pnas.90.3.1004

10. Bertina RM, Koeleman BPC, Koster T, Rosendaal FR, Dirven RJ, de Ronde HD, van der Velden PA and Reitsma PH. Mutation in blood coagulation factor $\mathrm{V}$ associated with resistance to activated protein C. Nature 369(6475): 64-67, 1994. http://dx.doi.org/10.1038/369064a0 PMid:8164741

11. Dahlbäck B. Resistance to activated protein $\mathrm{C}$ caused by the factor V R506Q mutation is a common risk factor for venous thrombosis. Thromb Haemost. 1997;78:483-488. PMid:9198201

12. Faioni EM, Razzari C, Martinelli I, Panzeri D, Franchi F, Mannucci PM. Resistance to activated protein $\mathrm{C}$ in unselected patients with arterial and venous thrombosis. Am J Hematol. 1997;55:59-64 http://dx.doi.org/10.1002/(SICI)1096- 
8652(199706)55:2<59::AID-AJH2>3.0.CO;2-1

13. Hoagland LE, Triplett DA, Peng F, et al. APC-resistnace as measured by a Textarin time assay: comparison to the APTTbased method. Thromb Res. 1996;83:363-373. http://dx.doi.org/10.1016/0049-3848(96)00146-6

14. Zöller B, Svensson PJ, He X, Dahlbäck B. Identification of the same factor $\mathrm{V}$ gene mutation in 47 out of 50 thrombosis-prone families with inherited resistance to activated protein C. J Clin Invest. 1994;94:2521-2524. http://dx.doi.org/10.1172/JCI117623 PMid:7989612 PMCid:330087

15. Alderborn A, Siegbahn A, Wadelius C. Venous thrombosis: factor V G1691A genetypeing related to APC resistance measured by 2 methods. Eur J Haematol. 1997;58:229-232. http://dx.doi.org/10.1111/j.1600-0609.1997.tb01659.x

16. Bontempo FA, Hassett AC, Faruki H, et al. The factor V Leiden mutation: spectrum of thrombotic events and laboratory evaluation. J Vasc Surg. 1997;25(2):271-275. http://dx.doi.org/10.1016/S0741-5214(97)70348-3

17. Florell SR, Rodgers GM. Inherited thrombotic disorders: An update. Am J Hematol. 1997;54:53-60. http://dx.doi.org/10.1002/(SICI)10968652(199701)54:1<53::AID-AJH8>3.0.CO;2-3

18. Samama MM, Simon D, Horellou MH, et al. Diagnosis and clinical characteristics of inherited activated protein $\mathrm{C}$ resistance. Haemostasis. 1996;26:315-330. PMid:8979137

19. Bengtsson A, Zöller B, de Frutos PG, Dahlbäck B and Sturfelt G. Factor V:Q506 mutation and anticardiolipin antibodies in systemic lupus erythematosus. Lupus 5(6): 598-601, 1996. http://dx.doi.org/10.1177/096120339600500607 PMid:9116703

20. Beauchamp NJ, Daly ME, Hampton KK, Cooper PC, Preston FE and Peake IR. High prevalence of a mutation in the factor $\mathrm{V}$ gene within the U.K. population: relationship to activated protein $\mathrm{C}$ resistance and familial thrombosis. Br J Haematol 88(1): 219222, 1994. http://dx.doi.org/10.1111/j.1365-2141.1994.tb05005.x PMid:7803250

21. Herrmann FH, Koesling M, Schroder W, Altman R, Jimenez Bonilla R, Lopaciuk S, Perez-Requejo JL and Singh JR. Prevalence of factor $\mathrm{V}$ Leiden mutation in various populations. Genet Epidemiol http://dx.doi.org/10.1002/(SICI) 1098 2272(1997)14:4<403::AID-GEPI5>3.0.CO;2-3

22. Aschka I, Aumann V, Bergmann F, Budde U, Ebert W, EckhofDonovan S, Krey S, Nowak-Gottl U, Schobess R, Sutor AH, Wendisch $\mathrm{J}$ and Schneppenheim R. Prevalence of factor V Leiden in children with thrombo-embolism. Eur J Pediatr 155(12): 1009-1014, 1996. http://dx.doi.org/10.1007/BF02532520 PMid:8956934

23. Schröder W, Koesling M, Wulff K, Wehnert M, Herrmann FH. Large-scale screening for factor $\mathrm{V}$ Leiden mutation in a northeastern German population. Haemostasis. 1996;26:233-6.

24. Hainaut P, Azerad MA, Lehmann E, Schlit AF, Zech F, Heusterspreute M, Philippe M, Col C, Lavenne E and Mariau M. Prevalence of activated protein $\mathrm{C}$ resistance and analysis of clinical profile in thromboembolic patients. A Belgian prospective study. J intern Med 241(5): 427-433, 1997. http://dx.doi.org/10.1046/j.1365-2796.1997.139145000.x PMid:9183312

25. Simkova M, Batorova A, Dostalova K, Pozgayova S, Simko F, Kovacs L. Factor V Leiden in patients with venous thrombosis in Slovak population. Gen Physiol Biophys. 2004;23:435-442 PMid:15815078

26. Hudecek J, Dobrotová M, Hybenová J, Ivanková J, Melus V, Pullmann R, Kubisz P. Factor V Leiden and the Slovak population. Vnitr Lek. 2003;49:845-850 PMid:14689680

27. Melichart M, Kyrle PA, Eichnger S, Rintelen C, Mannhalter C, Pabinger I. Thrombotic tendency in 75 symptomatic, unrelated patients with APC resistance. Wien Klin Wochenschr. 1996;108:607-610 PMid:8921576

28. Nagy A, Melegh B, Losonczy H. Study of the Leiden mutation (factor VQ506), the most frequent cause of thrombophilia, in 116 thrombosis patients. Orv Hetil. 1997;138:2797-2800 PMid:9411348

29. Stankovics J, Melegh B, Nagy A, Kis A, Molnar J, Losonczy H, Schuler A, Kosztolanyi G. Incidence of factor V G1681A (Leiden) mutation in samplings from the Hungarian population.
Orv Hetil. 1998;139:1161-1163 PMid:9613165

30. Djordjevic V, Rakicevic LJ, Mikovic D, Kovac M, Miljic P, Radojkovic D, Savic A. Prevalence of factor V leiden, factor V cambridge, factor II G20210A and methylenetetrahydrofolate reductase C677T mutations in healthy and thrombophilic Serbian populations. Acta Haematol. 2004;112:227-229. http://dx.doi.org/10.1159/000081280 PMid:15564739

31. Gurgey A, Mesci L. The prevalence of factor V Leiden (1691G ॰ A) mutation in Turkey. Turk J Pediatr. 1997;39:313-315 PMid:9339109

32. Olave T, Cornudella R, Homs C, Azaceta G, Tirado I, Gutierrez $\mathrm{M}$. Incidence and clinical manifestations of activated protein $\mathrm{C}$ resistance and factor $\mathrm{V}$ Leiden in young patients with venous thromboembolic disease in Spain. Haematologica. 1998;83:37880 PMid:9592991

33. García-Hernández MC, Romero Casanova A, Marco Vera P. Clinical comments on genetic marker prevalence (factor V Leiden, prothrombin 20210A and homozygous methylenetetrahydrofolate reductase form [Ho-MTHFR]): based on a study conducted in Health Department No. 19 of the Valencian Community. Rev Clin Esp. 2007;207:26-28. PMid:17306151

34. Aznar J, Vayá A, Estellés A, Mira Y, Seguí R, Villa P, Ferrando F, Falcó C, Corella D, España F. Risk of venous thrombosis in carriers of the prothrombin G20210A variant and factor $\mathrm{V}$ Leiden and their interaction with oral contraceptives. Haematologica. 2000;85:1271-1276 PMid:11114134

35. González Ordóñez AJ, Medina Rodriguez JM, Martín L, Alvarez $\mathrm{V}$, Coto $\mathrm{E}$. The $\mathrm{O}$ blood group protects against venous thromboembolism in individuals with the factor $\mathrm{V}$ Leiden but not the prothrombin (factor II G20210A) mutation. Blood Coagul Fibrinolysis. $\quad 1999 ; \quad 10$ : 303-307 http://dx.doi.org/10.1097/00001721-199907000-00013

36. Vargas M, Soto I, Pinto CR, Urgelles MF, Batalla A, RodriguezReguero J, Cortina A, Alvarez V, Coto E. The prothrombin 20210A allele and the factor V Leiden are associated with venous thrombosis but not with early coronary artery disease. Blood Coagul Fibrinolysis. 1999;10:39-41 http://dx.doi.org/10.1097/00001721-199901000-00006

37. Ricart JM, Vayá A, Todolí J, Calvo J, Villa P, Estellés A, España F, Santaolaria M, Corella D, Aznar J. Thrombophilic risk factors and homocysteine levels in Behçet's disease in eastern Spain and their association with thrombotic events. Thromb Haemost. 2006;95(4):618-624 PMid:16601831

38. Leroyer C, Mercier B, Escoffre M, Ferec C, Mottier D. Factor V Leiden prevalence in venous thromboembolism patients. Chest 1997;111: 1603-1606 http://dx.doi.org/10.1378/chest.111.6.1603 PMid:9187182

39. Mansourati J, Da Costa A, Munier S, Mercier B, Tardy B, Ferec C, Isaaz K, Blanc JJ. Prevalence of factor V Leiden in patients with myocardial infarction and normal coronary angiography. Thromb Haemost. 2000;83:822-825 PMid:10896232

40. Meyer G, Emmerich J, Helley D, Arnaud E, Nicaud V, AlhencGelas M, Aiach M, Fischer A, Sors H, Fiessinger JN. Factors V leiden and II 20210A in patients with symptomatic pulmonary embolism and deep vein thrombosis. Am J Med. 2001;110:12-15 http://dx.doi.org/10.1016/S0002-9343(00)00653-7

41. Mazoyer E, Ripoll L, Gueguen R, Tiret L, Collet JP, dit Sollier CB, Roussi J, Drouet L; FITENAT Study Group. Prevalence of factor V Leiden and prothrombin G20210A mutation in a large French population selected for nonthrombotic history: geographical and age distribution. Blood Coagul Fibrinolysis. 2009;20(7):503-510 http://dx.doi.org/10.1097/MBC.0b013e32832f5d7a

42. Bauder F, Ducout L, Guerre C, Freyburger G. Activated protein $\mathrm{C}$ (APC) resistance: does it exist in Basques? Br J Haematol 1997;99(3):712-713 PMid:9401095

43. Zabalegui N, Montes R, Orbe J, Ayape ML, Medarde A, Páramo JA, Rocha E. Prevalence of FVR506Q and prothrombin 20210A mutations in the Navarrese population. Thromb Haemost. 1998;80:522-523 PMid:9759640

44. Simioni P, Prandoni P, Lensing AW, Scudeller A, Sardella C, Prims MH, Villatta S, Dazzi F, Girolami A. The risk of recurrent venous thromboembolism in patients with an Arg506 $\diamond \mathrm{G}$ mutation in the gene for factor $\mathrm{V}$ (factor $\mathrm{V}$ Leiden). $\mathrm{N}$ Engl $\mathrm{J}$ 
Med.

1997;

http://dx.doi.org/10.1056/NEJM199702063360602

\section{PMid:9010145}

45. Sottilotta G, Mammì C, Furlò G, Oriana V, Latella C, Trapani Lombardo V. High incidence of factor $V$ Leiden and prothrombin G20210A in healthy southern Italians. Clin Appl Thromb Hemost. 2009; 15:356-359

46. Gessoni G, Valverde S, Canistro R, Manoni F. Factor V Leiden in Chioggia: a prevalence study in patients with venous thrombosis, their blood relatives and the general population. Blood Transfus. 2010;8:193-195 PMid:20671880 PMCid:2906187

47. Martinelli I, Battaglioli T, Bucciarelli P, Passamonti SM, Mannucci PM. Risk factors and recurrence rate of primary deep vein thrombosis of the upper extremities. Circulation. 2004; 110:566-570 http://dx.doi.org/10.1161/01.CIR.0000137123.55051.9B PMid:15262837

48. Mikovic D, Rakicevic L, Kovac M, Radojkovic D. Prevalence of factor V Leiden mutation in Yugoslav thrombophilic patients and its relationship to the laboratory diagnosis of APC resistance. Thromb Haemost. 2000;84:723-724 PMid:11057877

49. Bedencic M, Bozic M, Peternel P, Stegnar M. Major and potential prothrombotic genotypes in patients with venous thrombosis and in healthy subjects from Slovenia. Pathophysiol Haemost Thromb. 2008;36:58-63 PMid:19127083

50. Cikes V, Abaza I, Krzelj V, Terzić IM, Tafra R, Trlaja A, Marusić E, Terzić J. Prevalence of factor V Leiden and G6PD 1311 silent mutations in Dalmatian population. Arch Med Res. 2004;35:546-548

\section{http://dx.doi.org/10.1016/j.arcmed.2004.07.005} PMid:15631882

51. Coen D, Zadro R, Honović L, Banfić L, Stavljenić Rukavina A. Prevalence and association of the factor $\mathrm{V}$ Leiden and prothrombin G20210A in healthy subjects and patients with venous thromboembolism. Croat Med J. 2001;42:488-492 PMid:11471205

52. Jukic I, Bingulac-Popovic J, Dogic V, Babic I, Culej J, Tomicic M, Vuk T, Sarlija D, Balija M. ABO blood groups and genetic risk factors for thrombosis in Croatian population. Croat Med J. 2009;50:550-558 http://dx.doi.org/10.3325/cmj.2009.50.550 PMCid:2802088

53. Mekaj Y, Zhubi B, Hoxha H, Belegu R, Mekaj A, Miftari E, Belegu M. Prevalence of resistence to activated protein C (APCresistance) in blood donors in Kosovo. Bosn J Basic Med Sci. 2009;9:329-334 PMid:20002000

54. Hatzaki A, Anagnostopoulou E, Metaxa-Mariatou V, Melissinos C, Philalithis P, Iliadis K, Kontaxis A, Liberatos K, Pangratis N, Nasioulas G. The impact of heterozygosity for the factor $\mathrm{V}$ Leiden and factor II G20210A mutations on the risk of thrombosis in Greek patients. Int Angiol. 2003;22:79-82 PMid:12771861

55. Ioannou HV, Mitsis M, Eleftheriou A, Matsagas M, Nousias V, Rigopoulos C, Vartholomatos G, Kappas AM. The prevalence of factor $\mathrm{V}$ Leiden as a risk factor for venous thromboembolism in the population of North-Western Greece. Int Angiol. 2000;19:314-318 PMid:11305729

56. Antoniadi T, Hatzis T, Kroupis C, Economou-Petersen E, Petersen MB. Prevalence of factor V Leiden, prothrombin G20210A, and MTHFR C677T mutations in a Greek population of blood donors. Am J Hematol. 1999;61:265-267 http://dx.doi.org/10.1002/(SICI)10968652(199908)61:4<265::AID-AJH8>3.0.CO;2-\#

57. Lambropoulos AF, Foka Z, Makris M, Daly M, Kotsis A, Makris PE. Factor $\mathrm{V}$ Leiden in Greek thrombophilic patients: relationship with activated protein $\mathrm{C}$ resistance test and levels of thrombin-antithrombin complex and prothrombin fragment $1+$ 2. Blood Coagul Fibrinolysis. 1997;8:485-489 http://dx.doi.org/10.1097/00001721-199711000-00001

58. Limdi NA, Beasley TM, Allison DB, Rivers CA, Acton RT. Racial differences in the prevalence of Factor V Leiden mutation among patients on chronic warfarin therapy. Blood Cells Mol Dis. 2006;37:100-106 http://dx.doi.org/10.1016/j.bcmd.2006.06.003 PMid:16889993 PMCid: 1829476
59. Aboud MR, Ma DD. A comparrision between two activated protein $\mathrm{C}$ resistance methods as routine diagnostic tests for factor $\mathrm{V}$ Leiden mutation. $\mathrm{Br} \mathrm{J}$ Haematol. 1997; 97:798-803 http://dx.doi.org/10.1046/j.1365-2141.1997.1432958.x PMid:9217178

60. Gibson CS, MacLennan AH, Rudzki Z, Hague WM, Haan EA, Sharpe P, Priest K, Chan A, Dekker GA; South Australian Cerebral Palsy Research Group. The prevalence of inherited thrombophilias in a Caucasian Australian population. Pathology. 2005;37:160-163 http://dx.doi.org/10.1080/00313020500058250 PMid:16028846

61. Bennett JA, Palmer LJ, Musk AW, Erber WN. Prevalence of factor V Leiden and prothrombin 20210A mutations in indigenous Australians. Thromb Haemost. 2001;86:1592-1593 PMid:11776339

62. Gibson CS, MacLennan AH, Rudzki Z, Hague WM, Haan EA, Sharpe P, Priest K, Chan A, Dekker GA; South Australian Cerebral Palsy Research Group. The prevalence of inherited thrombophilias in a Caucasian Australian population. Pathology. 2005;37:160-163 http://dx.doi.org/10.1080/00313020500058250 PMid:16028846

63. Rosen E, Renbaum P, Heyd J, Levy-Lahad E. High frequency of factor V Leiden in a population of Israeli Arabs. Thromb Haemost. 1999;82:1768 PMid:10613668

64. Arruda VR, Annichino-Bizzacchi JM, Costa FF, Reitsma PH. Factor V Leiden (FVQ 506) is common in a Brazilian population. Am J Hematol. 1995;49:242-243 http://dx.doi.org/10.1002/ajh.2830490312 PMid:7604818

65. Zama T, Murata M, Ono F, Watanabe K, Watanabe R, Moriki T, Yokoyama K, Tokuhira M, Ikeda Y. Low prevalence of activated protein $\mathrm{C}$ resistance and coagulation factor V Arg506 to Gln mutation among Japanese patients with various forms of thrombosis, and normal individuals. Int J Hematol. 1996;65:71$78 \mathrm{http}: / / \mathrm{dx}$.doi.org/10.1016/S0925-5710(96)00527-0

66. Fujimura H, Kambayashi J, Monden M, Kato H, Miyata T. Coagulation factor $\mathrm{V}$ Leiden mutation may have a racial background. Thromb Haemost. 1995;74:1381-1382 PMid:8607128

67. Kodaira H, Ishida F, Scimodaira S, Takamiya O, Furihata K, Kitano K. Resistance to activated protein C and Arg506Gln factor $\mathrm{V}$ mutation are uncommon in eastern Asian populations. Acta Haematol. 1997; 98:22-25 http://dx.doi.org/10.1159/000203548 PMid:9210909

68. Ro A, Hara M, Takada A. The Factor V Leiden and the Prothrombin G20210A mutation was not found in Japanese patients with pulmonary thromboembolism. Thromb Haemost. 1999;82:1769

69. Kim TW, Kim WK, Lee JH, Kim SB, Kim SW, Suh C, Lee KH, Lee JS, Seo EJ, Chi HS, Kim SH. Low prevalence of activated protein $\mathrm{C}$ resistance and coagulation factor V Arg506 to Gln mutation among Korean patients with deep vein thrombosis. J Korean Med Sci. 1998;13:587-590 PMid:9886165 PMCid:3054550

70. Pepe G, Rickards O, Vanegas OC, Brunelli T, Gori AM, Giusti B, Attanasio M, Prisco D, Gensini GF, Abbate R. Prevalence of factor $\mathrm{V}$ Leiden mutation in non-European populations. Thromb Haemost. 1997;77:329-331 PMid:9157591

71. Ho CH, Chau WK, Hsu HC, Gau JP, Chih CM. Prevalence of factor V Leiden in the Chinese population. Zhonghua Yi Xue Za Zhi. 1999;62:875-878

72. Lim LC, Tan HH, Lee LH, Tien SL, Abdul Ghafar A. Activated protein $\mathrm{C}$ resistance: a study among 60 thromboembolic patients in the Singapore population. Ann Acad Med Singapore. 1999;28:252-255 PMid:10497677

73. Ghosh K, Shetty S, Madkaikar M, Pawar A, Nair S, Khare A, Pathare A, Jijina F, Mohanty D. Venous thromboembolism in young patients from western India: a study. Clin Appl Thromb Hemost. 2001;7:158-165 http://dx.doi.org/10.1177/107602960100700214 PMid:11292195

74. Nasiruddin, Zahur-ur-Rehman, Anwar M, Ahmed S, Ayyub M, Ali W. Frequency of factor V leiden mutation. J Coll Physicians Surg Pak. 2005;15:15-17 PMid:15670517

75. Gregg JP, Yamane AJ, Grody WW. Prevalence of the factor VLeiden mutation in four distinct American ethnic populations. $\begin{array}{lllll}\text { Am } & \mathrm{J} & \text { Med } & \text { Genet. } & \text { 1997;73:334-336 }\end{array}$ 
http://dx.doi.org/10.1002/(SICI)10968628(19971219)73:3<334::AID-AJMG20>3.0.CO;2-J

76. Abdulkadir J, Feleke Y, Berg JP, Falch JA and Odegaard OR. Absence of the factor V Leiden mutation in Ethiopians. Thromb Res. 1997;86:431-432 PMid:9211636

77. Vizcaino G, Torres E, Quintero J, Herrmann F, Grimm R, DiezEwald M, Arteaga-Vizcaino M, Perez-Requejo JL, ColinaAraujo J. Prevalence of the activated protein $\mathrm{C}$ resistance in indigenous and Black populations of the western Venezuela. Invest Clin. 2000;41:29-36 PMid:10758697

78. De Maat MPM, Kluft C, Jespersen J, Gram J. World distribution of factor $\mathrm{V}$ Leiden mutation. Lancet. 1996;347:58 http://dx.doi.org/10.1016/S0140-6736(96)91590-1

79. Mathonnet F, Nadifi S, Serazin-Leroy V, Dakouane M, Giudicelli Y. Absence of factor V Leiden mutation and low prothrombin G 20210 A mutation prevalence in a healthy Moroccan population. Thromb Haemost. 2002;88:1073-1074 PMid:12529766

80. They-They TP, Hamzi K, Moutawafik MT, Bellayou H, El Messal M, Nadifi S. Prevalence of angiotensin-converting enzyme, methylenetetrahydrofolate reductase, Factor V Leiden, prothrombin and apolipoprotein $\mathrm{E}$ gene polymorphisms in Morocco. Ann Hum Biol. 2010;37:767-777 http://dx.doi.org/10.3109/03014461003738850 PMid:20687780

81. Chafa O, Reghis A, Aubert A, Fischer AM. Prevalence of the FVQ506 (factor V Leiden) mutation in the normal and thrombophilic Algerian population. Br J Haematol. 1997;97:688689 PMid:9207426

82. Bourouba R, Houcher B, Djabi F, Egin Y, Akar N. The prevalence of methylenetetrahydrofolate reductase $677 \mathrm{C}-\mathrm{T}$, factor V $1691 \mathrm{G}-\mathrm{A}$, and prothrombin $20210 \mathrm{G}-\mathrm{A}$ mutations in healthy populations in Setif, Algeria. Clin Appl Thromb Hemost. 2009;15:529-534 http://dx.doi.org/10.1177/1076029608319944 PMid:18840629

83. Frere C, Saut N, Boukef MK, Zili M, Toumi NE. Factor V Leiden G1691A and prothrombin G20210A mutations are common in Tunisia. J Thromb Haemost 2003;1:2451-2452 http://dx.doi.org/10.1046/j.1538-7836.2003.0468b.x PMid:14629484

84. Bouaziz L, Hezard N, Touhami M, Potron G, N'siri B, Nguyen P. Allelic frequency of the factor $\mathrm{V}$ Leiden mutation and of the prothrombin gene $20210 \mathrm{~A}$ mutation in healthy Tunisian population. Thromb Haemost. 2004;91:824-825 PMid:15045148

85. Ajem A, Slama A, Slama FB, Mehjoub T. Prevalence of factor V leiden mutation in patients with thrombosis in Tunisia. East Mediterr Health J. 2009;15:1483-1488 PMid:20218141

86. Maalej L, Hadjkacem B, Ben Amor I, Smaoui M, Gargouri A, Gargouri J. Prevalence of factor V Leiden in south Tunisian blood donors. J Thromb Thrombolysis. 2011 [Epub ahead of print]

87. Zammiti W, Mtiraoui N, Mercier E, Abboud N, Saidi S, Mahjoub T, Almawi WY, Gris JC. Association of factor V gene polymorphisms (Leiden; Cambridge; Hong Kong and HR2 haplotype) with recurrent idiopathic pregnancy loss in Tunisia. A case-control study. Thromb Haemost. 2006;95:612-617. PMid:16601830

88. Mtiraoui N, Borgi L, Hizem S, Nsiri B, Finan RR, Gris JC, Almawi WY, Mahjoub T. Prevalence of antiphospholipid antibodies, factor V G1691A (Leiden) and prothrombin G20210A mutations in early and late recurrent pregnancy loss. Eur J Obstet Gynecol Reprod Biol. 2005;119:164-170. http://dx.doi.org/10.1016/j.ejogrb.2004.07.003

89. Almawi WY, Keleshian SH, Borgi L, Fawaz NA, Abboud N, Mtiraoui N, Mahjoub T. Varied prevalence of factor V G1691A (Leiden) and prothrombin G20210A single nucleotide polymorphisms among Arabs. J Thromb Thrombolysis. 2005;20:163-168 http://dx.doi.org/10.1007/s11239-005-3550-4 PMid:16261289

90. Klai S, Fekih-Mrissa N, Rachdi R, Gritli N. The status of thrombophilic defects and non-O blood group as risk factors for gestational vascular complications among Tunisian women. Acta Haematol. http://dx.doi.org/10.1159/000321934 PMid:21109732

91. Bouaziz-Borgi L, Nguyen P, Hezard N, Musharrafieh U, Almawi WY, Mahjoub T. A case control study of deep venous thrombosis in relation to factor V G1691A (Leiden) and A4070G (HR2 Haplotype) polymorphisms. Exp Mol Pathol. 2007;83:480483. http://dx.doi.org/10.1016/j.yexmp.2007.04.006 PMid: 17555744

92. Bouaziz-Borgi L, Almawi WY, Mtiraoui N, Nsiri B, Keleshian SH, Kreidy R, Louzir B, Hezard N, Mahjoub T. Distinct association of factor V-Leiden and prothrombin G20210A mutations with deep venous thrombosis in Tunisia and Lebanon. Am J Hematol. 2006;81:641-643. http://dx.doi.org/10.1002/ajh.20582 PMid:16823828

93. El-Karaksy H, El-Koofy N, El-Hawary M, Mostafa A, Aziz M, El-Shabrawi M, Mohsen NA, Kotb M, El-Raziky M, El-Sonoon MA, A-Kader H. Prevalence of factor V Leiden mutation and other hereditary thrombophilic factors in Egyptian children with portal vein thrombosis: results of a single-center case-control study. Ann Hematol. 2004;83:712-715 http://dx.doi.org/10.1007/s00277-004-0921-4 PMid:15309526

94. Abu-Skeen IA, Mohamed AA, Moustafa NN, Badawy ME. Factor V Leiden and prothrombin G20210A gene mutations in women with a history of thrombosis during pregnancy. Relation to pregnancy outcomes for mother and fetus. Saudi Med J. 2010;31:123-129 PMid:20174725

95. Maher MM, Soloma SH. Assessment of thrombophilic abnormalities during the active state of inflammatory bowel disease. Saudi J Gastroenterol. 2008;14:192-197 http://dx.doi.org/10.4103/1319-3767.41743 PMid:19568537 PMCid:2702936

96. Settin A, Dowaidar M, El-Baz R, Abd-Al-Samad A, El-Sayed I, Nasr M. Frequency of factor V Leiden mutation in Egyptian cases with myocardial infarction. Hematology. 2008;13:170-174. http://dx.doi.org/10.1179/102453308X316158 PMid:18702875

97. Dashti AA, Jadaon MM, Lewis HL. Factor V Leiden mutation in Arabs in Kuwait by real-time PCR: different values for different Arabs. J Hum Genet. 2010;55:232-235 http://dx.doi.org/10.1038/jhg.2010.11 PMid:20224595

98. Hussein AS, Darwish H, Shelbayeh K. Association between factor V Leiden mutation and poor pregnancy outcomes among Palestinian women. Thromb Res. 2010;126:e78-82. http://dx.doi.org/10.1016/i.thromres.2010.04.017 PMid:20605623

99. Irani-Hakime N, Tamim H, Elias G, Finan RR, Daccache JL, Almawi WY. High prevalence of factor V mutation (Leiden) in the Eastern Mediterranean. Clin Chem. 2000;46:134-136 PMid:10620589

100. Taher A, Khalil I, Shamseddine A, El-Ahdab F, Bazarbachi A High prevalence of Factor $\mathrm{V}$ Leiden mutation among healthy individuals and patients with deep venous thrombosis in Lebanon: is the eastern Mediterranean region the area of origin of this mutation? Thromb Haemost. 2001;86:723-724 PMid:11522037

101. Tamim H, Finan RR, Almawi WY. Prevalence of two thrombophilia predisposing mutations: factor V G1691A (R506Q; Leiden) and prothrombin G20210A, among healthy Lebanese. Thromb Haemost. 2002;88:691-692 PMid:12362248

102. Finan RR, Tamim H, Ameen G, Sharida HE, Rashid M and Almawi WY. Prevalence of factor V G1691A (factor V-Leiden) and prothrombin G20210A gene mutations in a recurrent miscarriage population. Am J Hematol. 2002;71:300-305 http://dx.doi.org/10.1002/ajh.10223 PMid:12447960

103. Isma'eel H, Arnaout MS, Shamseddeen W, Mahfouz R, Zeineh N, Jradi O, Taher A. Screening for inherited thrombophilia might be warranted among Eastern Mediterranean sickle-beta-0 thalassemia patients. J Thromb Thrombolysis. 2006;22:121-123 http://dx.doi.org/10.1007/s11239-006-8953-3 PMid:17008978

104. Zahed LF, Rayes RF, Mahfouz RA, Taher AT, Maarouf HH, Nassar AH. Prevalence of factor V Leiden, prothrombin and methylene tetrahydrofolate reductase mutations in women with adverse pregnancy outcomes in Lebanon. Am J Obstet Gynecol. 2006; 195:1114-1118 http://dx.doi.org/10.1016/j.ajog.2006.06.082 PMid:17000243

105. Isma'eel H, El Accaoui R, Shamseddeen W, Taher A, Alam S, Mahfouz R, Arnaout MS. Genetic thrombophilia in patients with VTE in eastern Mediterranean located tertiary care center; is it time to change the algorithm for thrombophilia work up decision making? J Thromb Thrombolysis. 2006;21:267-270 
http://dx.doi.org/10.1007/s11239-006-5537-1 PMid:16683219

106. Irani-Hakime N, Tamim H, Elias G, Choueiry S, Kreidy R, Daccache JL, Almawi WY. Factor V R506Q mutation-Leiden: an independent risk factor for venous thrombosis but not coronary artery disease. J Thromb Thrombolysis. 2001;11:1111116 http://dx.doi.org/10.1023/A:1011268531377 PMid: 11406725

107. Irdem A, Devecioglu C, Batun S, Soker M, Sucakli IA. Prevalence of factor V Leiden and prothrombin G20210A gene mutation. Saudi Med J. 2005;26:580-583 PMid:15900364

108. Diz-Kucukkaya R, Hancer VS, Artim-Esen B, Pekcelen Y, Inanc M. The prevalence and clinical significance of inherited thrombophilic risk factors in patients with antiphospholipid syndrome. J Thromb Thrombolysis. 2010;29:303-309 http://dx.doi.org/10.1007/s11239-009-0356-9 PMid:19504051

109. Celiker G, Can U, Verdi H, Yazici AC, Ozbek N, Atac FB. Prevalence of thrombophilic mutations and ACE I/D polymorphism in Turkish ischemic stroke patients. Clin Appl $\begin{array}{lll}\text { Thromb } & \text { Hemost. } & \text { 2009;15:415-420 }\end{array}$ http://dx.doi.org/10.1177/1076029608315163 PMid:18387982

110. Oguzulgen IK, Yilmaz E, Demirtas S, Erkekol FO, Ekim N, Demir N, Numanoglu N, Ozel D, Ulu A, Akar N. The role of plasminogen activator inhibitor-1 polymorphism, factor-VLeiden, and prothrombin-20210 mutations in pulmonary thromboembolism. Clin Appl Thromb Hemost. 2009;15:73-77 http://dx.doi.org/10.1177/1076029607305110 PMid:18160588

111. Kabukcu S, Keskin N, Keskin A, Atalay E. The frequency of factor $\mathrm{V}$ Leiden and concomitance of factor $\mathrm{V}$ Leiden with prothrombin G20210A mutation and methylene tetrahydrofolate reductase C677T gene mutation in healthy population of Denizli, Aegean region of Turkey. Clin Appl Thromb Hemost. 2007;13:166-171 http://dx.doi.org/10.1177/1076029606298990 PMid:17456626

112. Kalkanli S, Ayyildiz O, Tiftik N, Batun S, Isikdogan A, Ince H, Tekes S, Muftuoglu E. Factor V Leiden mutation in venous thrombosis in southeast Turkey. Angiology. 2006:57:193-196 http://dx.doi.org/10.1177/000331970605700209 PMid:16518527

113. Atasay B, Arsan S, Günlemez A, Kemahli S, Akar N.Factor V Leiden and prothrombin gene 20210A variant in neonatal thromboembolism and in healthy neonates and adults: a study in a single center. Pediatr Hematol Oncol. 2003;20:627-634 PMid: 14578033

114. Gurgey A, Haznedaroglu IC, Egesel T, Buyukasik Y, Ozcebe OI, Sayinalp N, Dundar SV, Bayraktar Y. Two common genetic thrombotic risk factors: factor $\mathrm{V}$ Leiden and prothrombin G20210A in adult Turkish patients with thrombosis. Am J Hematol. 2001;67:107-111 http://dx.doi.org/10.1002/ajh.1087 PMid:11343382

115. Ozbek U, Tangün Y. Frequency of factor V Leiden in Turkey. Int J Hematol. 1996;64:291-292 http://dx.doi.org/10.1016/0925$\underline{5710(96) 00499-9}$

116. Angelopoulou K, Nicolaides A, Constantinou Deltas C. Prevalence of genetic mutations that predispose to thrombophilia in a Greek Cypriot population. Clin Appl Thromb Hemost. 2000;6:104-107 http://dx.doi.org/10.1177/107602960000600211 PMid:10775032

117. Eid SS, Rihani G. Prevalence of factor V Leiden, prothrombin G20210A, and MTHFR C677T mutations in 200 healthy Jordanians. Clin Lab Sci. 2004; 17:200-202 PMid:15559724

118. Eid SS, Shubeilat T. Prevalence of Factor V Leiden, prothrombin G20210A, and MTHFR G677A among 594 thrombotic Jordanian patients. Blood Coagul Fibrinolysis. 2005;16:417-421 http://dx.doi.org/10.1097/01.mbc.0000175478.46831.52

119. Awidi A, Shannak M, Bseiso A, Kailani MAM, Kailani MA, Omar N, Anshasi B, Sakarneh N. High Prevalence of Factor V Leiden in Healthy Jordanian Arabs. Thromb Haemost. 1999;41:582-584

120. Obeidat NM, Awidi A, Sulaiman NA, Abu-Khader IB Thrombophilia-related genetic variations in patients with pulmonary embolism in the main teaching hospital in Jordan. Saudi Med J. 2009:30:921-925 PMid:19618008

121. Nusier MK, Radaideh AM, Ababneh NA, Qaqish BM, Alzoubi R, Khader Y, Mersa JY, Irshaid NM, El-Khateeb M. Prevalence of factor V G1691A (Leiden) and prothrombin G20210A polymorphisms among apparently healthy Jordanians. Neuro
Endocrinol Lett. 2007;28:699-703 PMid:17984931

122. Al-Sweedan SA, Jaradat S, Iraqi M, Beshtawi M. The prevalence of factor V Leiden (G1691A), prothrombin G20210A and methylenetetrahydrofolate reductase $\mathrm{C} 677 \mathrm{~T}$ mutations in Jordanian patients with beta-thalassemia major. Blood Coagul Fibrinolysis.

2009;20:675-678 http://dx.doi.org/10.1097/MBC.0b013e3283315b4f

123. Dashti AA, Jadaon MM. Race differences in the prevalence of the factor V Leiden mutation in Kuwaiti nationals. Mol Biol Rep. 2010.

http://dx.doi.org/10.1007/s11033-010-0474-7 PMid:21104134

124. Jadaon MM, Dashti AA, Lewis HL. High prevalence of activated protein $\mathrm{C}$ resistance and factor $\mathrm{V}$ Leiden mutation in an Arab population and patients with venous thrombosis in Kuwait. Diagn $\quad$ Mol Pathol. 2010;19:180-183 http://dx.doi.org/10.1097/00019606-201009000-00009 PMid:20736749

125. Dzimiri N, Meyer B. World distribution of factor V Leiden. Lancet. 1996;347:481-482 http://dx.doi.org/10.1016/S01406736(96)90064-1

126. Almawi WY, Tamim H, Kreidy R, Timson G, Rahal E, Nabulsi M, Finan RR, Irani-Hakime N. A case control study on the contribution of factor V-Leiden, prothrombin G20210A, and MTHFR C677T mutations to the genetic susceptibility of deep venous thrombosis. J Thromb Thrombolysis. 2005;19:189-196 http://dx.doi.org/10.1007/s11239-005-1313-x PMid:16082606

127. Pathare A, Al Kindi S, Al Haddabi H, Dennison D, Bayoumi R, Muralitharan S. Hereditary thrombophilia in ethnic Omani patients. Am J Hematol. 2006;81:101-106 http://dx.doi.org/10.1002/ajh.20525 PMid:16432849

128. Pawar AR, Shetty S, Ghosh K, Mohanty D. How old is Factor V Leiden mutation? Thromb Haemost. 2001;86:1591-1592 PMid:11776338

129. Zeinali S, Duca F, Zarbakhsh B, Tagliabue L, Mannucci PM. Thrombophilic mutations in Iran. Thromb Haemost 2000;83:351-352 PMid:10739401

130. Mozafari H, Rahimi Z, Heidarpour A, Fallahi M, Muniz A. The prevalence of factor $\mathrm{V}$ Leiden, prothrombin G20210A and methylenetetrahydrofolate reductase polymorphism C677T among G6PD deficient individuals from Western Iran. Mol Biol Rep. 2009;36:2361-3264 http://dx.doi.org/10.1007/s11033-0099458-x PMid:19219640

131. Rahimi Z, Nomani H, Mozafari H, Vaisi-Raygani A, Madani H, Malek-Khosravi S, Parsian A. Factor V G1691A, prothrombin G20210A and methylenetetrahydrofolate reductase polymorphism C677T are not associated with coronary artery disease and type 2 diabetes mellitus in western Iran. Blood Coagul Fibrinolysis. 2009;20:252-256 http://dx.doi.org/10.1097/MBC.0b013e3283255487

132. Rahimi Z, Ghaderi M, Nagel RL, Muniz A. Prevalence of thrombotic risk factors among beta-thalassemia patients from Western Iran. J Thromb Thrombolysis. 2008;26:229-233 http://dx.doi.org/10.1007/s11239-007-0163-0 PMid:17982733

133. Rahimi Z, Mozafari H, Shahriari-Ahmadi A, Alimogaddam K, Ghavamzadeh A, Aznab M, Mansouri K, Rezaei M, Parsian A. Deep venous thrombosis and thrombophilic mutations in western Iran: association with factor $\mathrm{V}$ Leiden. Blood Coagul Fibrinolysis. http://dx.doi.org/10.1097/MBC.0b013e328330e69a

134. Lucotte G, Mercier G. Population genetics of factor V Leiden in Europe. Blood Cells Mol Dis. 2001;27:362-367 http://dx.doi.org/10.1006/bcmd.2001.0388 PMid:11259157

135. Cox MJ, Rees DC, Martinson JJ, Clegg JB. Evidence of a single origin of factor V Leiden. Br J Haematol 92(4):1022-1025, 1996. http://dx.doi.org/10.1046/j.1365-2141.1996.4961037.x PMid:8616062

136. Rees DC, Cox M and Clegg JB. World distribution of factor V Leiden. Lancet 346(8983): 1133-1134, 1995. http://dx.doi.org/10.1016/S0140-6736(95)91803-5

137. Perry DJ and Pasi KJ. Resistance to activated protein $\mathrm{C}$ and factor V Leiden. Q J Med 90(6): 379-385, 1997

138. Castoldi E, Lunghi B, Mingozzi F, Ioannou P, Marchetti G, Bernardi $F$. New coagulation factor $V$ gene polymorphisms define a single and infrequent haplotype underlying the factor $\mathrm{V}$ Leiden mutation in Mediterranean populations and Indians. 
Thromb Haemost. 1997;78:1037-1041 PMid:9308750

139. Bauduer F, Lacombe D. Factor V Leiden, prothrombin 20210A, methylenetetrahydrofolate reductase $677 \mathrm{~T}$, and population genetics. Mol Genet Metab 2005;86:91-99 http://dx.doi.org/10.1016/j.ymgme.2005.04.002 PMid:16185908

140. Jadaon MM, Dashti AA, Lewis HL. What is the origin of factor $\mathrm{V}$ Leiden mutation in Arabs? The first molecular proof. J Thromb Haemost. 2011;9: P-MO-155. 